\title{
教育講演
}

\section{IgG4 関連疾患の新たな展開}

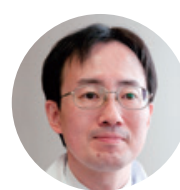

高橋裕樹

Key words IgG4関連疾患 (IgG4-RD)，Mikulicz病，抗laminin-511抗体，Tph細胞

\section{はじめに}

IgG4 (immunoglobulin G4) 関連疾患 (IgG4-related disease : IgG4-RD）とは, 血清IgG4 高值と $\operatorname{IgG} 4$ 陽性形質細胞の浸潤, 線維化による臓器の 腫瘤性，結節性ならびに肥厚性病変を呈する全 身性慢性疾患である。従来, Mikulicz病と呼称 されていた涙腺・唾液腺病変と自己免疫性膵炎 (autoimmune pancreatitis：AIP）を二大病変と し, 加えて, 胆管, 腎, 後腹膜・大動脈周囲な らびに肺等に時間的多発性をもって病変が出現 する疾患として，本邦から提唱された新たな概 念である ${ }^{1)}$. IgG4-RDを構成する病変は, 従来, 特発性の線維炎症性病態あるいはSjögren症候 群 (Sjögren's syndrome：SS）等の既存疾患の非 典型例と判断されていたが, 21 世紀初頭に浜野 らにより報告されたAIPでの血清IgG4 高值と, 病変におけるIgG4陽性形質細胞の浸潤を最たる 特徵として独立した疾患概念として確立された。

2011 年には, 厚生労働省研究班において,
IgG4-RD包括診断基準（comprehensive diagnostic criteria：CDC）が策定され, 疾患の認知度の 向上と共に報告数が飛躍的に増加し, また, 病 因・病態に関する新たな知見が本邦を中心に報 告されている2)。これら病態に関わる免疫関連 分子・細胞の詳細な解析により, 新たなバイオ マーカーや治療標的としての臨床応用が期待さ れている.ただし, IgG4 関連のデータを過大評 価するあまり, IgG4-RDの過剩診断も散見され ることから, 診断基準 - 分類基準の見直しが行 われている(表1).

本稿では, IgG4-RDの臨床像を概説し, さらに, 病因・病態の解明, 診断基準の改訂ならびに新 規治療の 3 点における最近の進歩を紹介する.

\section{IgG4関連疾患の臨床像}

IgG4-RDは, 全身性の慢性炎症性疾患と捉え られるが，発熱等の全身症状はみられない。診 断の契機は, 緩徐に腫瘤性・結節性の病変が形 


\section{表 1 lgG4関連疾患包括診断基準 2020}

(厚生労働省「lgG4関連疾患の診断基準並びに診療指針の確立を目指す研究」班より)

【項目 1 : 臨床的, 画像的診断】

単一*または複数臓器に特徵的なびまん性あるいは限局性腫大，腫瘤，結節，肥厚性病変を認める。

(*リンパ節が単独病変の場合は除く)

【項目 2: 血清学的診断】

高lgG4血症（135 mg/dI以上）を認める.

【項目 $3:$ 病理学的診断】

以下の3項目中2つを満たす.

(1)著明なリンパ球・形質細胞の浸潤と線維化を認める.

(2) IgG4陽性形質細胞浸潤：IgG4/lgG陽性細胞比 40\%以上，かつlgG4陽性形質細胞が 10/hpfをこえる.

(3)線維化とくに花筵様線維化あるいは閉塞性静脈炎のいずれかを認める.

項目 1) +2) +3）を満たすもの：確診群 (definite)

項目 1）+3）を満たすもの：準確診群（probable）

項目 1）＋2）を満たすもの：疑診群（possible）

(注釈 1) 臟器別診断基準の併用

本基準で，準確診群（probable），疑診群（possible）であっても，lgG4関連臟器別診断基準**で確定診断されたものは，lgG4 関 連疾患確診群 (definite) と判断する。

* ${ }^{*}$ gG4 関連臓器別診断基準：(1)自己免疫性膵炎診断基準，(2) lgG4関連ミクリッツ病診断基準，(3) IgG4関連腎症診断基準，44lgG4関 連硬化性胆管炎臨床診断基準，(5) IgG4関連眼疾患診断基準，(6) gG4関連呼吸器疾患診断基準，7) IgG4関連疾大動脈周囲炎/動脈周 囲炎および後腹膜線維症診断基準

(注棌2) 除外診断

1）出来うる限り組織診断を行い，各臟器の悪性腫瘍（癌，悪性リンパ腫など）や類似疾患（Sjögren 症候群，原発性硬化性胆管炎， Castleman病，二次性後腹膜線維症，多発血管炎性肉芽腫症，サルコイドーシス，好酸球性多発血管炎性肉芽腫症など）を鑑別する ことが重要である.

2）高熱，高CRP，好中球増多などを呈する場合，感染性・炎症性疾患を除外することが重要である.

(注釈3) 病理学的診断

経皮・内視鏡下針生検に比べ，摘出・部分切除標本では， $\operatorname{lgG} 4$ 陽性細胞数は通常多く認められる. 本疾患は共通する病理像が特徴 ではあるが，数值にこだわり過ぎない総合的な評価が重要である.

(注釈4) ステロイド反応性

ステロイド治療を積極的に推奨するものではないが，ステロイド治療に全く反応しない場合，診断を再考する必要がある. hpf : high power field

成されることから, 罹患臓器の位置や隣接臓器 との関係に左右される。好発罹患部位として は, 涙腺・唾液腺, 膵, 胆管, 腎, 後腹膜・大 動脈周囲ならびに肺があり，これらの部位が罹 患臓器の $95 \%$ 以上を占めるとされている3). た だし, 複数の臓器病変が同時期に出現するとは 限らず，時間経過を含めて評価しなければ全体 像が把握しにくい.

涙腺・唾液腺や膵等の好発臓器の腫大や高力゙ ンマグロブリン血症・高IgG血症等の血清学的 異常から, IgG4-RDが疑われた場合には，CDCな いしは臓器毎の診断基準に従い, 診断を確定す る ${ }^{1)}$. CDCの要旨は, (1)単一または複数臓器にび まん性あるいは限局性腫大, 腫瘤, 結節, 肥厚
性病変を認めること, (2)高IgG4 血症（135 mg/ dl以上) を認めること, (3)病理組織学的に1) 組 織所見：著明なリンパ球・形質細胞の浸潤と線 維化を認める, 2) IgG4陽性形質細胞浸潤：IgG4/ $\operatorname{IgG}$ 陽性細胞比 $40 \%$ 以上, 且つ 10 個以上/強拡 大視野をこえること，の3項目よりなる．従っ て, CDCでは, ある一定のボリュームを有した 病変と IgG4 関連データが確認されなければ IgG4-RDの診断が確定されない.ただし, 臓器 毎の診断基準による診断も可能である.

\section{IgG4 関連疾患の病因・病態の解明}

IgG4-RDでは，しばしば高ガンマグロブリン 


\section{表2 IgG4関連疾患の自己抗体}

\begin{tabular}{|c|c|c|c|c|c|}
\hline $\begin{array}{l}\text { 報告者 } \\
\text { (年) }\end{array}$ & 自己抗原 & 対象疾患 & 自己抗原の同定方法 & 測定方法 & 陽性率 \\
\hline $\begin{array}{l}\mathrm{Du} \\
(2015)\end{array}$ & prohibitin & lgG4関連疾患 & $\begin{array}{c}\text { ヒト培養細胞溶解物と } \\
\text { 患者血清を用いた免疫沈降法 }\end{array}$ & 酵素抗体法 & $73 \%$ \\
\hline $\begin{array}{l}\text { Hubers } \\
(2018)\end{array}$ & annexin A11 & $\begin{array}{l}\text { 自己兔疫性膵炎 } \\
\text { 硬化性胆管炎 }\end{array}$ & $\begin{array}{c}\text { ヒト培養胆管細胞溶解物と } \\
\text { 患者血清を用いた免疫沈降法 }\end{array}$ & 酵素抗体法 & $\begin{array}{l}14 \%(\operatorname{lgG} 1) \\
18 \%(\operatorname{lgG} 4)\end{array}$ \\
\hline $\begin{array}{l}\text { Shiokawa } \\
\text { (2018) }\end{array}$ & $\begin{array}{l}\operatorname{laminin}-511 \\
(\mathrm{LM}-511)\end{array}$ & 自己免疫性膵炎 & $\begin{array}{c}\text { 患者由来IgG1/G4が組織基底膜に反応 } \rightarrow \\
\text { 患者血清で基底膜構成蛋白をスクリーニング }\end{array}$ & 酵素抗体法 & $\begin{array}{c}51 \% \\
(\lg \mathrm{G} 1>\mathrm{G} 4)\end{array}$ \\
\hline $\begin{array}{l}\text { Perugino } \\
\text { (2017) }\end{array}$ & galectin-3 & lgG4関連疾患 & $\begin{array}{l}\text { 形質芽細胞由来のモノクローナル抗体に } \\
\text { よるimmunoaffinity chromatography }\end{array}$ & 酵素抗体法 & $\begin{array}{l}28 \%(\operatorname{lgG} 4) \\
11 \%(\lg \mathrm{E})\end{array}$ \\
\hline
\end{tabular}

血症や低補体血症がみられ, また, 多臟器罹患 と慢性の経過と併せて基盤に免疫異常の存在が 想定されていた.ただし, IgG4 はIgG1〜 IgG3 と 異なり, 補体活性化能・FC受容体結合能が低い 等, 免疫グロブリンとしてのエフェクター機能 に乏しく, 病変形成への直接的な関与を疑問視 する意見が多かった. 併行して自己抗原の解析 も精力的に進められたが, 特定の抗原同定には 至らなかった。

しかし, 近年, IgG4-RD患者血中にオリゴク ローナルな形質芽細胞（plasmablast：PB）や限 定したレパトアを有するT細胞の存在が認めら れ, 特定の抗原により免疫細胞が誘導されてい る可能性が指摘された。 実際, IgG4-RDに関連 した自己抗体が複数報告されている（表2）.

Shiokawaらは, AIP患者から分離精製したIgG またはIgGサブクラスを新生仔マウスに投与し たところ, IgG1 とIgG4により, 膵では小葉間の 浮腫性解離, 壊死・出血, 多形核白血球の浸潤, 唾液腺では浮腫性変化を誘発されたことを報告 し，AIP患者血清中に病原性を有するIgGが存在 することを示した. その後, 対応抗原の 1 つと して, 基底膜を構成するlaminin-511（LM-511） を報告した ${ }^{3)}$. LM-511を抗原とした酵素抗体法 により，抗LM-511 抗体はAIP群51例中26例 (51\%)，コントロール群 122 例中2例（1.6\%） で陽性であり,さらに，抗LM-511抗体陽性の AIPは陰性例と比較し, 悪性腫瘍・アレルギー疾
患の合併, 膵頭部罹患が少ないという臨床的特 徵を示した. 一方, Peruginoらは, IgG4-RD患者 血中で認められたオリゴクローナルなPB由来 のモノクローナル抗体を用いたimmunoaffinity chromatographyにより, 自己抗原としてレクチ ンの1つであるgalectin-3を同定した. また, Du らとHubersらは, 患者血清とヒト培養細胞溶解 物を用いた免疫沈降法により, 対応抗原とし て，それぞれprohibitinとannexin A11 (ANX) を 同定した.ただし, Liuらがこれら自己抗体を検 証したところ, 抗LM-511 IgG1 抗体6\%, 抗ANX IgG4 抗体 $12 \%$, 抗prohibitin IgG4 抗体 10\%とい ずれもコントロールと有意差が示されず4), 今 後, 自己抗体の病因的意義や臨床的な有用性に 関しては検証が必要である.

IgG4-RDの病態におけるT細胞の役割に関し て、これまでTh2 と制御性T細胞 (regulatory $\mathrm{T}$ cell : Treg) 優位の免疫応答が確認されていた. Th2由来のIL (interleukin)-4・IL-13はIgE (immunoglobulin E) やIgG4の産生充進, また, Tregか ら産生されるIL-10 は選択的にIgG4へのクラス スイッチを促進し得ることから, これらT細胞 サブセットの偏位と, サイトカインの過剩発現 がIgG4-RDの病態の主体と考えられていた. 特 に最近は, 抗IL-4/IL-13受容体抗体であるdupilumabのIgG4-RDに対する有効例も報告されて いる.

また, 胚中心の形成に不可欠であり, 抗体産 
生に関わる濾胞性ヘルパーT（follicular helper $\mathrm{T}$ ：Tfh）細胞のIgG4-RDへの関連も注目されて いる。Tfhは, CXCR5 陽性のCD4+T細胞であり， 転写因子Bcl-6の発現が分化には必須である. Tfhの表面マーカーとしては，その他，PD-1 (programmed cell death 1), ICOS (inducible T-cell costimulator) ならびにBTLA (B-and T-lymphocyte attenuator）4が知られている. Akiyama らは, 未治療, 活動性のIgG4-RD症例を対象に, 末梢血に存在するTfhとそのサブセット（Tfh1, Tfh2ならびにTfh17）について解析し，SSや健 常人,アレルギー性鼻炎に比して, Tfh2 細胞数 は有意に増加していること，血清 $\operatorname{IgG} 4$ 值や IgG4/IgG比, PB数と強く相関していることを報 告した ${ }^{5)}$.また, Kamekuraらは, IgG4-RD, 特に IgG4 関連涙腺・唾液腺炎を対象に顎下腺局所及 び末梢血におけるTfhの発現を検討したところ， 活性化TfhはSSやコントロールに比較し有意に 増加していた ${ }^{6)}$. 活性化したTfhは, 機能的にも IgG4 産生をへルプする能力が高く, IgG4-RDの 臨床パラメーターと相関することは, 病態にお けるTfhの重要性を裏付けるものと考えられる.

Tfhと並ぶキープレイヤーとして, 最近, granzyme A（GZMA）を発現するCD4+T細胞で ある, 細胞傷害性Tリンパ球 (cytotoxic T-lymphocyte : CTL) とperipheral helper T (Tph) 細 胞が注目されている. Mattooらは, IgG4-RD患 者末梢血中で増加していたeffector memory T細 胞の遺伝子発現を解析したところ, GZMA等の 細胞傷害性蛋白やIFN (interferon)- $\gamma$ 産生する CD4+CTLがオリゴクローナルに増加している こと, 罹患臟器に浸潤し, PBと同様, 細胞表面 にSLAMF7 (signaling lymphocytic activation molecule family member 7）を発現していることを 報告した 7 . また, 病変部位におけるCD4+CTL の割合が, 血中 IgG4 值や罹患臓器数と相関する ことからも, IgG4-RDの病態に直接関わってい る可能性が示された。また, 近年, 関節リウマ チ滑膜にIL-21 産生能を有し, B細胞の成熟に働
くものの, Tfh細胞と異なり, CXCR5 陰性のTph が見出された. TphはCX3CR1 (fractalkine受容 体）等の多くのケモカイン受容体を発現してお り, 炎症部位に集積することから, 自己免疫疾 患での役割が注目されている. Kamekuraらは, IgG4-RD患者末梢血において, PD-1+CXCR5-CD4+のTph様細胞がSSや健常人に比較し 増加していること, 血中 IgG4 值や罹患臓器数と 相関しており, GC (glucocorticoid) 治療後に有 意に低下することを報告し，Tfhと共同し， IgG4-RDの病変を形成する機序が想定された8) (図)。これら Tphは細胞傷害性蛋白を有し，血 管内皮や導管上皮に対して細胞傷害性に働くこ とも確認され, IgG4-RDの組織障害・線維化を 惹起する役割も示唆されている.

\section{IgG4関連疾患の診断基準の改訂}

IgG4-RDは, 2015年 7 月から本邦の指定難病 に認定されており，その診断は前述したCDCな いしは臓器毎の診断基準に従って行われてい る。また, IgG4-RDに包含される呼吸器疾患・ 眼疾患 $\cdot$ 大動脈周囲炎/動脈周囲炎及び後腹膜 線維症 - 甲状腺疾患 - 視床下部下垂体炎 - 肥厚 性硬膜炎それぞれの診断基準が学会・厚労省研 究班で策定されている11. しかしながら, IgG4-RDに関する知見・経験が増加し, また, 国際的には, 米国・欧州リウマチ学会合同とし

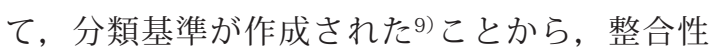
を勘案し, 現行のCDCの見直しが厚労省研究班 に拉いて行われている(表1). 現行のCDCから の改訂のポイントは, (1)旧基準では, 著明なリ ンパ球・形質細胞浸潤と線維化及びIgG4 陽性細 胞浸潤を必須としていたが，新基準では, リン パ球・形質細胞浸潤, IgG4 陽性細胞浸潤, 線維 化ないしは閉塞性静脈炎の 3 点中 2 点としたこ と, (2)新基準では, リンパ節単独病変では IgG4-RDと診断しないこと, (3)除外診断におい て, 各疾患に加え, 高熱, 高CRP (C-reactive 


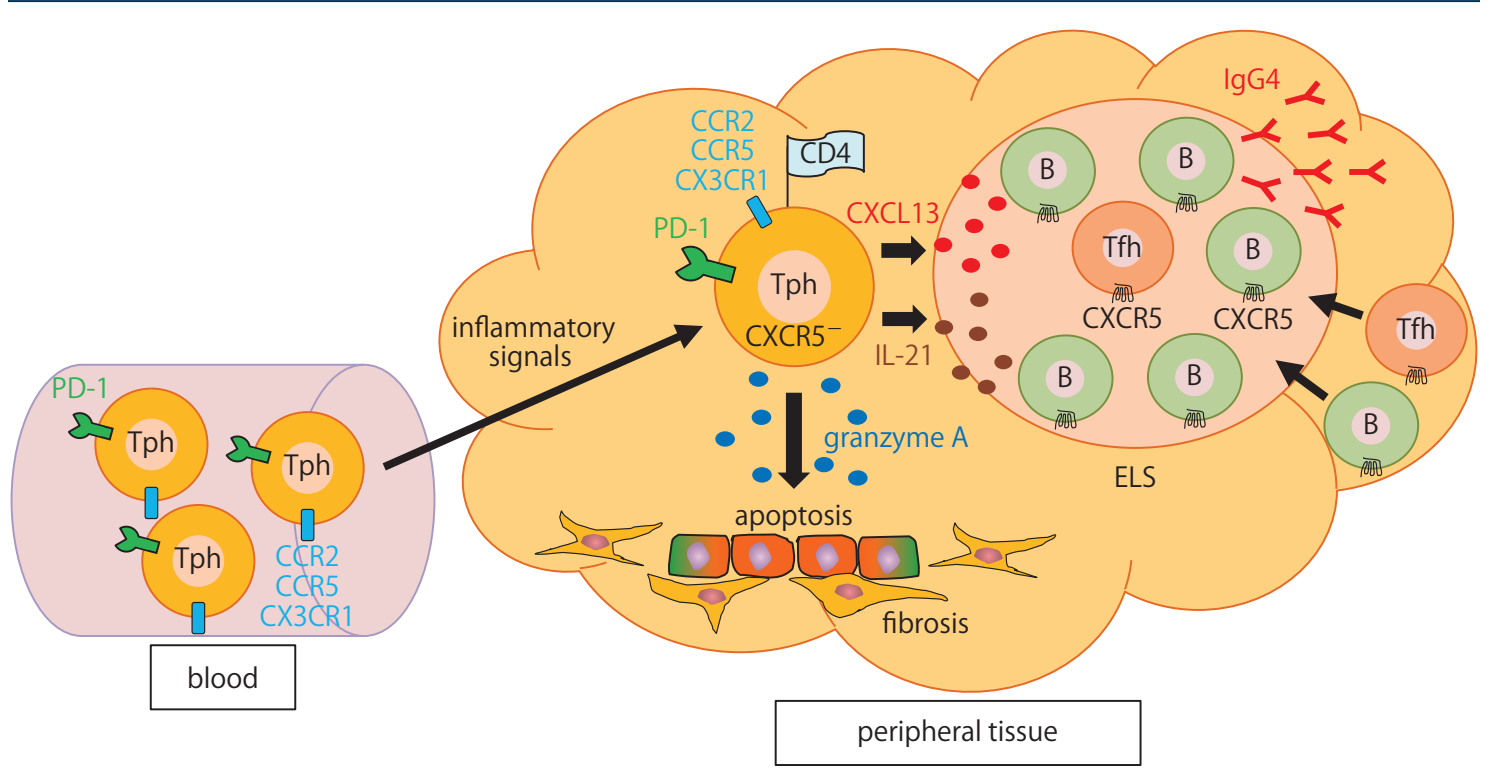

図 lgG4関連疾患の病態形成におけるTph細胞・Tfh細胞の役割（文献8より）

Tph細胞はケモカイン受容体（CCR2，CCR5ならびにCXCR1）を高発現しており，IgG4-RDの病変部に浸潤する. Tph細胞が産生するCXCL13はCXCR5陽性のTfhやBの遊走を誘導し，IgG4関連病変部に異所性リンパ組織 (ectopic lymphoid structures：ELS）が形成され，局所でのlgG4産生が促進する．また，Tph細胞はGZMA等の細胞傷害 性因子を高産生し，病変形成に関与する。

$\mathrm{B}: \mathrm{B}$ cell

protein)，好中球増多を呈する場合と明記した こと等が挙げられる。また, IgG4 関連Mikulicz 病も IgG4 関連涙腺・唾液腺炎としての診断基準 改訂を行っている. 旧基準では，対称性に2ペ ア以上の涙腺・唾液腺の腫大が 3 力月以上みら れる場合は，高IgG4 血症があれば，CDCと異な り，病理組織所見を欠いても診断可能としてい た。その妥当性に関しては，さらに厳密な検証 が必要であるが, 涙腺・唾液腺病変の特徴的な 臨床像を反映しており, 口唇腺の有用性含め, 可及的生検施行が望ましいことを追記したうえ で採用し，一方，1ペアのみあるいは片側のみ の涙腺・唾液腺病変に対しても適用可能な基準 への改訂を予定している（日本シェーグレン症 候群学会ホームページ参照).

米国・欧州リウマチ学会合同で策定された IgG4-RDの分類基準は, 臨床試験や国際的な疫 学研究を行う際にIgG4-RDを抽出するための厳
密な基準であり，罹患臓器を膵，唾液腺，胆管， 眼窩, 腎, 肺, 動脈, 後腹膜, 脳硬膜ならびに 甲状腺に限定（entry criteria）し，また，除外 基準（exclusion criteria）を設定したうえで，各 臓器病変や病理組織学的検査に比重をかけてス コアリング（inclusion criteria）し，診断する方 法をとっている。特に発熱, GC不応, 血球減少 ならびに自己抗体陽性等の除外基準は, 実臨床 でIgG4-RDを診断する場合に参考になる ${ }^{9)}$.

今後, 非侵襲的且つ精度の高い診断基準の策 定が求められて打り, 前述した自己抗体や工 コー, ${ }^{18} \mathrm{~F}$-FDG-PET ( ${ }^{18} \mathrm{~F}$-fluorodeoxyglucose positron emission tomography), MRI (magnetic resonance imaging) 等の画像診断の応用も検討 されている. 


\section{IgG4関連疾患の新規治療}

IgG4-RD治療の第一選択薬はGCであること は，国際的にもコンセンサスが得られている一 方, GCによる維持療法の必要性・期間, 免疫抑 制薬（immunosuppressive agent：IM）併用の適 否, 分子標的療法の有効性に関しては, 結論が 出ていない.AIPでは, 3年間をGCの維持療法の 目安としており, その後の中止も選択肢として 挙げられている一方, IgG4-RDでは, 低用量で 維持中に再燃が高頻度に生じることも経験され ており，涙腺・唾液腺炎を主体とした当科での GC中止・完全寛解例は $10 \%$ 以下である.このた め, GC減量・中止効果を期待し, 既存の膠原病 治療に使用されるIM等が試みられている。二重 盲験無作為化比較試験は未施行であるが, 海外 で行われた 15 件の臨床試験（米国 5 件, 中国 3 件等) でのIgG4-RD 1,169例の治療成績を対象に GC, IMならびにリツキシマブ (rituximab：RTX) の有効性等がメタ解析されている10). 寛解導入 に関しては, GC・IM併用が最も有効であり, 次 いで, GC・RTX併用, GC単独, RTX寛解, IM単 独の順であった。再燃抑制に関しては, RTXに よる寛解維持療法が最も有効であり, 次いで, GC・IM併用, IM単独, RTX寛解, GC単独の順 に評価された。ただし，特定のIMの有効性は明 らかにはされていない. ただし, 近年, オープ ン試験ではあるが，寛解導入時から無作為化の うえ, MMF (mycophenolate mofetil) やレフル ノミド (leflunomide : LEF) 併用とPSL単独療法 の比較が報告されており, 寛解導入・再燃抑制 に有効であると報告されている ${ }^{11)}$. 本邦では, IgG4-RDを難治性のリウマチ性疾患と位置付け ると, AZA（azathioprine）のみが保険適用内と 考えられるが，いずれもエビデンスは未だ十分 ではなく, 今後の検証を要する.

一方, IgG4-RDの病態が分子レベルで明らか にされつつあり, 分子標的療法の応用も期待さ れている。現時点で, 有用性の報告が目立つの
は抗CD20抗体であるRTXである. RTXは, CD20 陰性のPBや形質細胞への直接傷害性はないが, B細胞が枯渇することで自己抗体の産生やT細 胞への抗原提示が抑制され, IgG4-RDの病態改 善が期待される. 実際, Carruthersらは, IgG4-RD 30例（平均罹病期間 5.8 年, $73 \%$ にGC使用歴あ り）でのRTXの使用成績を報告している。この うち, 26 例はRTX単独治療であり, 臨床的反応 は $97 \%$ に認められ, 投与 6 力月後の時点で responder index (RI) 2点以上の低下を示したの は $77 \%$ であった. 有効例の約半数はGCフリーの 完全寛解を維持していたことから，GC非併用下 でもRTXが有効であることが示唆された。 また, Wallaceらは, IgG4-RD 60例（平均罹病期間 6.1 年, $57 \%$ にGC使用歴あり）でのRTXの使用成績 と再燃予測因子を報告した ${ }^{12)}$. 41 例はGC非併用 下であったが, 臨床的反応はほぼ全例でみられ た.ただし，21例（37\%）は平均35週後に再 燃を認め, 再燃予測因子として治療前の血清 $\operatorname{IgG} 4$ 值・IgEと好酸球数が抽出された. 以上か ら, RTXは完全寛解には至らないものの, GCフ リーでもIgG4-RDをコントロールできることか ら, IgG4-RDの治療標的としてのB細胞の重要性 を示した. 同様に, B細胞表面のCD19に対する $\mathrm{XmAb}^{\circledR} 5871$ を用いた臨床試験も報告され，15 例中 14 例でRI 5 点以上の低下がみられた. 同抗 体はB細胞表面の抑制性シグナルを入れる Fc $\gamma$ 受 容体IIbへの親和性を高めるよう Fc 部分が改変 されている一方, RTXと異なり, B細胞を枯渇さ せない可逆的な抗体であり，RTXで懸念される 日和見感染症等の副作用の軽減が期待される. また, B細胞の生存・分化・抗体産生に重要な BAFF (B cell-activating factor belonging to the tumor necrosis factor family)に対する抗体 (belimumab）が有効であった症例報告もある.

一方, T細胞活性化阻害作用を有するabataceptの有効性が報告されたが, IgG4-RDの特殊性 を考慮すると, 前述したTfhやCD4+CTLが治療標 的として想定される.TfhとB細胞の相互作用を 
阻害するICOS ligandに対するモノクローナル抗 体である prezalumab, CD4+CTLに発現が増加し ているSLAMF7 に対する elotuzumabの臨床応用 も想定される13).

\section{おわりに}

IgG4-RDは，21世紀に入り，全身性線維炎症 性疾患として確立した新規疾患概念である。特 にIgG4を中心に病態が解明されていく過程に 本邦からの多くの業績が貢献しており, 現在も 厚労省の研究班を主体として活発な研究が行わ
れている. 病態の解明は, 診断や活動性の判定 に有用なバイオマーカーの発見に結び付く可能 性が高く, 最近, 見出された自己抗体について も，測定キットの開発や臨床的有用性の検証が 待たれる。また, GC主体の治療により, 長期例 では再燃やGCの副作用が不可避となりつつあ り, 適切な分子標的療法の究明が急務となって きている.

著者のCOI（conflicts of interest）開示: 本論文発表内容 に関連して特に申告なし

\section{文献}

1）岡崎和一：全身疾患として診るIgG4 RD. 日内会誌 $109:$ 399-411, 2020.

2) Takahashi $\mathrm{H}$, et al : The birthday of a new syndrome : IgG4-related diseases constitute a clinical entity. Autoimmun Rev 9 : 591-594, 2010.

3) Shiokawa M, et al : Laminin 511 is a target antigen in autoimmune pancreatitis. Sci Transl Med $10,2018$.

4) Liu $\mathrm{H}$, et al : Disease severity linked to increase in autoantibody diversity in IgG4-related disease. Arthritis Rheumatol $72: 687-693,2020$.

5) Akiyama M, et al : Number of circulating follicular helper $2 \mathrm{~T}$ cells correlates with IgG4 and interleukin-4 levels and plasmablast numbers in IgG4-related disease. Arthritis Rheumatol 67 : 2476-2481, 2015.

6) Kamekura R, et al : Cutting edge : a critical role of lesional $\mathrm{T}$ follicular helper cells in the pathogenesis of IgG4-related disease. J Immunol 199 : 2624-2629, 2017.

7) Mattoo $\mathrm{H}$, et al : Clonal expansion of $\mathrm{CD}^{+}$cytotoxic $\mathrm{T}$ lymphocytes in patients with IgG4-related disease. J Allergy Clin Immunol 138 : 825-838, 2016.

8) Kamekura R, et al : New insights into IgG4-related disease : emerging new CD4+ T-cell subsets. Curr Opin Rheumatol $31: 9-15,2019$.

9) Wallace ZS, et al : The 2019 American College of Rheumatology/European League Against Rheumatism classification criteria for IgG4-related disease. Ann Rheum Dis 79 : 77-87, 2020.

10) Omar $\mathrm{D}$, et al : Glucocorticoids and steroid sparing medications monotherapies or in combination for IgG4-RD : a systematic review and network meta-analysis. Rheumatology $59: 718-726,2020$.

11) Yunyun F, et al : Efficacy and safety of low dose mycophenolate mofetil treatment for immunoglobulin G4-related disease : a randomized clinical trial. Rheumatology 58 : 52-60, 2019.

12) Wallace ZS, et al : Predictors of disease relapse in IgG4-related disease following rituximab. Rheumatology 55 : 1000-1008, 2016.

13) Perugino $\mathrm{CA}$, et al : Emerging treatment models in rheumatology : IgG4-related disease : insights into human immunology and targeted therapies. Arthritis Rheum 69 : 1722-1732, 2017. 